\title{
Effect of Immersion in Calcium Chloride Solution on the Characteristic of Coconut Chips during Storage
}

\author{
Rindengan Barlina ${ }^{1}$, Linda Trivana ${ }^{2}$, and Engelbert Manaroinsong ${ }^{3}$
}

\begin{abstract}
The quality of coconut chips can be increased, through efforts to improve processing by immersing the coconut meat in $\mathrm{CaCl}_{2}$ solution. The various concentrations of $\mathrm{CaCl}_{2}$ solution are $0.0 \%$, $0.5 \%, 1.0 \%, 1.5 \%$, and $2.0 \%$. Furthermore, the effect of treatments was evaluated on the characteristic of coconut chips for 0 months, 2 months, 4 months, and 6 months of storage in plastic coated aluminum foil packaging. The results showed that coconut chips from DMT coconut meat with fruit 9 months old contain $2.36-2.49 \%$ moisture, $2.36-2.55 \%$ ash, $3.87-5.35 \%$ protein, $37.31-45.35 \%$ fat, 50.15-53.23\% carbohydrate and 4.93-5.48\% crude fiber. Immersion in $\mathrm{CaCl}_{2}$ solution and storage time increased the water content of coconut chips. The results of organoleptic testing showed that coconut chips still preferred by respondent up to 6 months of storage. The higher concentration of $\mathrm{CaCl}_{2}$ solution was used, resulting in smaller pressure (gram force) to break or destroy coconut chips, which can be interpreted that coconut chips have a crispness that is still good. Next, the color measurement uses Chromameter Konica Minolta CR-400, L (Lightness) value to 6 months ranged from 76.39-77.65, which indicated that the color of the product is still predominantly bright white.
\end{abstract}

Key words: Coconut chips, quality, storage

\section{Introduction}

The rapid development of the population in Indonesia has forced the government to make various breakthroughs to provide food reserves especially rice (Rindengan, 2018). Rice can supply approximately $50 \%$ calorie needs from the recommended calorie standard of $2200 \mathrm{kcal} / \mathrm{capita} /$ day (Susenas, 2003 in Nainggolan, 2004). As a coconut producing country, coconut has actually the potential to be utilized in providing some of the daily nutritional needs.

In Indonesia, consuming snacks has become a separate lifestyle especially in urban communities. It is shown by the increasing number of types of snacks circulating in traditional markets and supermarkets. Hence, a portion of calorie requirement could be fulfilled by consuming snacks. Raw materials used for snacks processing, for example, are tubers, fruits, and livestock by-product like skin. Besides that, it can also come from coconuts, such as by -product of coconut oil processing with wet extraction, namely coconut pulp and 9 months aged young coconut meat (Rindengan et al., 2004).

\footnotetext{
${ }^{1}$ Postharvest Technology, Indonesian Palmae Crops Research Institute (IPCRI), Jl. Raya Mapanget, PO Box 1004, Manado, North Sulawesi, Indonesia. Email: barlina_rindengan@yahoo.com

2 Postharvest Technology, Indonesian Palmae Crops Research Institute (IPCRI), Jl. Raya Mapanget, PO Box 1004, Manado, North Sulawesi, Indonesia. Email: lindatrivana@gmail.com

${ }^{3}$ Research Service Division, Indonesian Palmae Crops Research Institute (IPCRI), J1. Raya Mapanget, PO Box 1004, Manado, North Sulawesi, Indonesia. Email: Eng_man2001@yahoo.com
} 
Coconut is currently only considered as a source or raw material for making cooking oil, actually neglecting its potential as a source of alternative nutritional components (Rindengan, 2018). Other than using it as raw material for producing cooking oil and virgin coconut oil, coconut meat can also be a source of protein, carbohydrate, fiber, vitamins, and minerals. Coconut meat can be classified as a good source of protein because it does not contain antinutrient compounds such as those found in legumes.In addition, coconut meat from young and mature nuts, has a fairly good nutritional composition so that it can be utilized for processing a variety of appropriate food products. Coconut meat with fruit age 9 months of GKB x DMT hybrid contains $73.66 \%$ water, $1.81 \%$ ash, $2.50 \%$ protein, $13.06 \%$ fat, $8.97 \%$ carbohydrate, and $5.05 \%$ crude fiber (Rindengan, et al., 1996). Besides that, it has a composition of omega 9 fatty acids or oleic acid (C18:1, n-9) $7.95 \%$ and omega 6 or linoleic acid (C18:2, n-6) 1.81\% (Rindengan, 2002). Omega 9 fatty acids are very important for maturation of the functions of brain nerve cells, which mostly occur from birth to the fourth age. While omega 6 is an essential fatty acid that is very necessary from the time of conception until the first two years of the child's age (Anonim, 2002). According to FAO and $\mathrm{WHO}$, the standard of additional food for infants and children must contain linoleic acid (omega 6) 1.4gr/100 gr.

In Balitpalma (IPCRI), the processing of snacks/ coconut chips use an oven dryer at $90^{\circ} \mathrm{C}$ for 2 hours and then continued at $70^{\circ} \mathrm{C}$ for 3 hours to reduce water content of coconut chips (Rindengaan, et al. 2004), without the addition of Food Additives to improve the crunchy properties and storability of the product. Food additives like calcium chloride $\left(\mathrm{CaCl}_{2}\right)$ as calcium salt is soluble in water and is extensively used to improve the texture of processed fruit and vegetable products. It is also utilized to obtain the crispy texture of chips because it can reduce the decomposition of cells which cause softening of the tissue. Calcium chloride can also inhibit the growth of microorganisms (Tuwitii, 2010).
The result of Sari's research (2010), showed that the highest quality of papaya chips is obtained with immersion in $1,5 \% \mathrm{CaCl}_{2}$. On the other hand, according to Nisak (2007), the highest quality of papaya chips is obtain with immersion in $\mathrm{CaCl}_{2}$ solution for 40 minutes. In the Philippines, coconut chips can be processed at age 9-10 months and 12 months. This product has been exported to various countries, including Germany, Sweden, Canada, and Denmark with price range \$115 US to \$1562 US (Masa and Montecillo, 2002). The objective of the research was to determine the influence of immersion in $\mathrm{CaCl}_{2}$ on the characteristics of coconut chips during storage.

\section{Materials and Methods}

\section{Materials}

The materials used are young coconut meat (age 9 months) of Mapanget Tall (DMT) coconut variety. Mapanget Tall (DMT) coconut variety originated from Mapanget District, North Sulawesi Province, Indonesian. The description of Mapanget Tall (DMT) coconut is an age of first flowering 5 years, age of first harvesting 6 years, number of bunches 12-14/palm/year, number of nuts $90 / \mathrm{palm} /$ year and 12.870 nuts/ha (Balitpalma, 2018).

\section{Methods}

\section{Processing of Coconut Chips}

The coconut meat is separated from the shell and then the testa layer was removed. Then it is thinly sliced to about $4-5 \mathrm{~cm}$ long using knife. The sliced coconut meat is immersed in $\mathrm{CaCl} 2$ solution for 12 hours. The concentration of $\mathrm{CaCl}_{2}$ solution are a1) $0.0 \%$, a2) $0.5 \%$, a3) $1.0 \%$, a4) $1.5 \%$, and a5) $2.0 \%$. Then, drained and added with $20 \%$ sugar solution, boiled for 30 minutes and dried using oven Memmet UFB-500 type. Drying is done at temperature of $90^{\circ} \mathrm{C}$ for the first 2 hours and then reduced to temperature of $70^{\circ} \mathrm{C}$ for succeeding 3 hours (Rindengan, et al, 2004).

Furthermore, the coconut chips are packaged using aluminum foil (plastic coated) making it easier to glue. Then, packed coconut chips are stored for 0 months (b1), 2 months 
(b2), 4 months (b3), and 6 months (b4). The research was conducted in two replications.

\section{Evaluation of Coconut Chips Quality}

Moisture content, protein, fat, ash, and crude fiber were determined following the standard methods of the Association of Official Analytical Chemist (1995), starch (Anthrone Method, AOAC 197),carbohydrate content was determined by subtracting of $100 \%$ with the total sum of water content, ash, protein, and fat in sample (Winarno, 1986). Organoleptic test (color, flavor, taste, and crispness) with scale $1=$ really dislike, $2=$ dislike, $3=$ normal, $4=$ like, and $5=$ really like, use 20 respondents (Soekarto, 1985). Color analyzed by Chromametermethod (Ramsey, 2012) using Chromameter Konica Minolta CR-400 type and The crispness using Texture Analyzer (Peleg and Bagley, 1983).

\section{Statistical Analysis}

Observations data were analyzed using SPSS 16.0. If there is a difference between treatments followed by DMRT Test (Duncan Multiple Range Test)

\section{Result and Discussion}

\section{Composition of Raw Material and Coconut Chips}

The composition of DMT coconut meat from 9 months old fruit which was used for making coconut chips is shown in Table 1 . The crude fiber content of $4,58 \%$ is a good component as a raw material for snacks. Hence, the product produced is expected to have high crude fiber which can help the metabolic process in the body.

The composition of coconut chips at immersion treatments in $\mathrm{CaCl}_{2}$ solution with concentrations of $0-2.0 \%$ are shown in Table 2 . The composition of coconut chips immersed in $\mathrm{CaCl}_{2}(0-2.0 \%)$ solutions has moisture contents ranging from $2.36-2.49 \%$, ash $2.36-2.59 \%$, protein $3.87-4.65 \%$, fat $37.31-40.25 \%$, carbohydrate $50.13-53.23 \%$, crude fiber 4.93 $5.48 \%$, while starch is not detected. According to Butler (2019), 6 gramsof 10 grams carbohydrate contained in coconut flour is dietary fiber, while the remaining 4 grams is crude fiber and soluble fiber. Therefore, starch is not detected as well as amylose.

Based on the results obtained, all the nutritional components of coconut chip were increased compared with the raw material (fresh coconut meat) because the water content in fresh coconut meat of about $70 \%$ has evaporated at the drying process, so that the nutrient component is concentrated.

The composition of coconut chips produced by Coconut Development Board, Kochi-India with coconut meat at age 8-10 months as raw material and the composition (per 20 gram) is fat 9.42 gram, lauric acid 4.82 gram, crude fiber 1.93 gram, calcium 2.10 gram, iron $1.30 \mathrm{mg}$, and cholesterol 0.00 gram (Anonim, 2019). While, the composition of coconut chips (per 100 gram) produced from Thailand is energy 77 calories, fat 3.6 gram, protein 1.4 gram, fiber 3 gram, carbohydrate 10.3 gram, calcium $43 \mathrm{mg}$, phosphorus $56 \mathrm{mg}$, iron $1.0 \mathrm{mg}$, and vitamin C $6 \mathrm{mg}$ (Anonim, 2005). On the other hand, according to Sanchez, et al. (1996), the composition of dried buko chips is $4.7 \%$ moisture content, $3.6 \%$ protein, $17.7 \%$ fat, and $61.6 \%$ carbohydrate for sweetened type. The unsweetened type has a composition of $2.3 \%$ moisture content, $7.7 \%$ protein, $51.4 \%$ fat, and $13.6 \%$ carbohydrate. Differences in the results obtained may be caused by raw material used, processing, and use of food additives. In Indonesia, the standard quality for chips is based on the raw materials used, but the one for coconut chips is not yet available.

\section{Moisture Content of Coconut Chips}

Statistic analysis results show that the concentration of $\mathrm{CaCl}_{2}$ solution has effect on the level of coconut chips' water content (Figure 1). Moisture content at immersion in $0-1.5 \% \mathrm{CaCl}_{2}$ solution is $1.47-1.76 \%$, and increased to $2.52 \%$ at immersion in $2 \% \mathrm{CaCl}_{2}$ solution. This is due to the hygroscopic characteristic of $\mathrm{CaCl}_{2}$ (Kemp, et al. 2000). Hence, the water content of coconut chips increases with the higher concentration of $\mathrm{CaCl}_{2}$ solution. 
Table 1. Composition of DMT coconut meat with fruit age of 9 months

\begin{tabular}{|l|l|c|c|c|}
\hline No. & \multicolumn{1}{|c|}{ Observed } & Unit & DMT & $\begin{array}{c}\text { DMT, fruit age 12 } \\
\text { months }\end{array}$ \\
\hline 1. & Moisture content & $\%$ & 72.90 & 49.80 \\
\hline 2. & Ash & $\%$ & 0.64 & - \\
\hline 3. & Protein & $\%$ & 2.37 & 3.32 \\
\hline 4. & Fat & $\%$ & 9.09 & 20.21 \\
\hline 5. & Carbohydrate & $\%$ & 15.00 & 5.37 \\
\hline 6. & Crude fiber & $\%$ & 4.58 & 2.81 \\
\hline
\end{tabular}

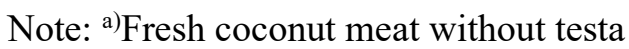

${ }^{b)}$ Tenda, et.al (1997)

Table 2. Composition of coconut chips immersed in $\mathrm{CaCl}_{2}(\mathbf{0 - 2 . 0} \%)$ solution*)

\begin{tabular}{|l|l|c|l|l|l|l|l|}
\hline \multirow{2}{*}{ No. } & \multirow{2}{*}{ Observation } & \multirow{2}{*}{ Unit } & \multicolumn{6}{|c|}{$\mathrm{CaCl}_{2}(\%)$} \\
\cline { 6 - 9 } & & & & 0.5 & 1.0 & 1.5 & 2.0 \\
\hline 1. & Moisture content & $\%$ & 2.42 & 2.45 & 2.48 & 2.49 & 2.36 \\
\hline 2. & Ash & $\%$ & 2.59 & 2.55 & 2.47 & 2.39 & 2.36 \\
\hline 3. & Protein & $\%$ & 4.45 & 4.65 & 5.35 & 3.87 & 4.32 \\
\hline 4. & Fat & $\%$ & 37.31 & 37.55 & 39.57 & 39.29 & 40.25 \\
\hline 5. & Carbohydrate & $\%$ & 53.23 & 52.80 & 50,13 & 51.96 & 50.71 \\
\hline 6. & Crude Fiber & $\%$ & 5.30 & 5.48 & 4.93 & 5.32 & 5.12 \\
\hline 7. & Starch & $\%$ & 0 & 0 & 0 & 0 & 0 \\
\hline
\end{tabular}

*) after drying and cooling

Table 3. Effect of immersion in $\mathrm{CaCl}_{2}$ solution on characteristics organoleptic test of coconut chips

\begin{tabular}{|c|c|c|c|c|}
\hline \multirow{2}{*}{$\begin{array}{l}\text { Immersion in } \mathrm{CaCl}_{2} \\
\text { solution }\end{array}$} & \multicolumn{4}{|c|}{ Organoleptic Test } \\
\cline { 2 - 5 } & Color & Flavor & Taste & Crispness \\
\hline $0.0 \%$ & $3.57 \mathrm{a}$ & $3.63 \mathrm{a}$ & $4.01 \mathrm{a}$ & $3.95 \mathrm{a}$ \\
\hline $0.5 \%$ & $3.69 \mathrm{a}$ & $3.38 \mathrm{a}$ & $3.89 \mathrm{a}$ & $3.84 \mathrm{a}$ \\
\hline $1.0 \%$ & $3.66 \mathrm{a}$ & $3.41 \mathrm{a}$ & $3.76 \mathrm{a}$ & $3.97 \mathrm{a}$ \\
\hline $1.5 \%$ & $3.69 \mathrm{a}$ & $3.35 \mathrm{a}$ & $3.73 \mathrm{a}$ & $3.74 \mathrm{a}$ \\
\hline $2.0 \%$ & $3.63 \mathrm{a}$ & $3.45 \mathrm{a}$ & $3.86 \mathrm{a}$ & $3.82 \mathrm{a}$ \\
\hline
\end{tabular}

Note: Numbers followed by the different letter at the same column are significantly differenced at $5 \%$ of DMRT 
According to Sanchez, et al. (1996), the moisture content of dried buko chips for sweetened type and unsweetened type is $4.7 \%$ and $2.3 \%$, respectively. The Philippine standard for fancy cut desiccated coconut for which coconut chips can be categorized specifies a moisture content below $4 \%$. However, for the other types of desiccated coconut, the Philippine standard stipulates a maximum moisture content of 3\% (PCA Administrative Order No. 003, Series of 1981). Based on Figure 1, Immersion in $2 \% \mathrm{CaCl}_{2}$ solution increased the moisture content of coconut chips to $2.52 \%$ but it's still within the limit of the maximum set for desiccated coconut.

Figure 2 showed that the length of storage time has an influence on the moisture content of coconut chips. The moisture content of coconut chip up to 6 months of storage is $2.2 \%$. Nevertheless, it is still far too compared than the standard of the moisture content of cassava chips (6.0\%) and dried buko chips for sweetened type and unsweetened type is $4.7 \%$ and $2.3 \%$, respectively (PCA Administrative Order No. 003, Series of 1981).

\section{Characteristics of Coconut Chips}

\section{3a. Organoleptic test}

Value of organoleptic test is scale $1=$ really dislike, $2=$ dislike, $3=$ normal, $4=$ like, and $5=$ really like. Effect of immersion in $0-2 \%$ $\mathrm{CaCl}_{2}$ solution and storage time on the results of color, flavor, taste, and crispness value of coconut chips can be seen in Table 3 and Table 4.

Based on Table 3, immersion in $0-2.0 \%$ $\mathrm{CaCl}_{2}$ solution has no effect on the organoleptic test of coconut chips. Values for colors range from 3.57 to 3.69 (normal to near like), flavor 3.35-3.63 (normal to near like), taste3.76-4.01 (close to likes), and crispness 3.74-3.97 (close to likes). Furthermore, in Table 4, the storage time did not have an effect on flavor and taste of coconut chips. Range of flavor values 3.44-3.56 (normal to near like) and taste 3.75-3.91 (normal to near like). However, color and crispness of coconut chips are influenced by storage time.Color values of the organoleptic test at storage time up to 6 months 3.80 (close to like) and crispness 4.09 (like). The crispness of coconut chips that lasts until 6 months of storage, probably caused by using packaging materials made of plastic coated aluminum foil (Figure 3), so the product is protected.

\section{3b. Crispness analysis using texture analyzer}

The crispness of coconut chips can be measured by the organoleptic test and using crispness measuring devices i.e. Texture Analyzer. The results of the texture analyzer are shown in Figure 4. Break values of coconut chips influenced by the concentration of $\mathrm{CaCl}_{2}$ but storage time not affected. Based on Figure 4, higher of $\mathrm{CaCl}_{2}$ concentration in immersion, the break values decreases. This proves that only a smaller pressure is needed in gram force for a break or destroy the coconut chips, which can be interpreted that coconut chips have a good crispness. Crispness values of organoleptic test not influenced by $\mathrm{CaCl}_{2}$ concentration but a range of crispness values $3.82-3.97 \%$ (normal to near like).

The measurement results crispness of cassava chips without treatment (control) were performed by Ginting (2014) is 500 gram force compared than the results obtained of immersion in $0-20 \% \mathrm{CaCl}_{2}$ solution give a range break values only $100.39-137.73$ gram force, that means coconut chips need only a smaller pressure in gram force compared than cassava chips. This might also because by a characteristic of raw materials used, coconut meat not contain starch, while cassava contains $73 \%$ starch.

\section{3c. Measuring the color of coconut chips using Chromameter Konica Minolta CR-400}

The measurement of color using a Chromameter Konica Minolta CR-400 obtained values like L (Lightness: between $0-100$ is white), a (range red and green color 0-60), and b (range yellow and blue color 0-60). The results of measuring the color of coconut chips showed in Table 5 . 


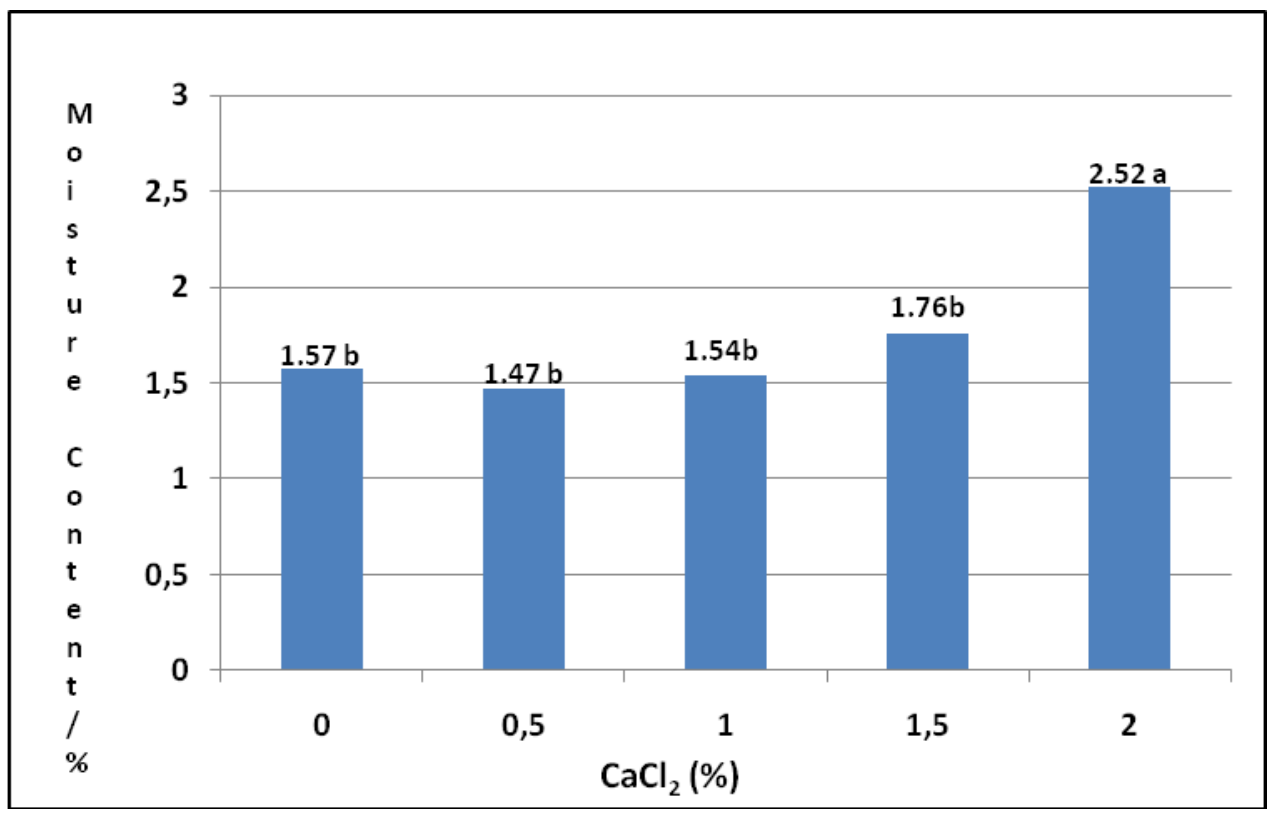

Note: Numbers followed by the different letter at the graph are significantly differenced at $5 \%$ of DMRT

Figure 1. Effect of immersion in $\mathrm{CaCl}_{2}$ solution on the moisture content of coconut chips

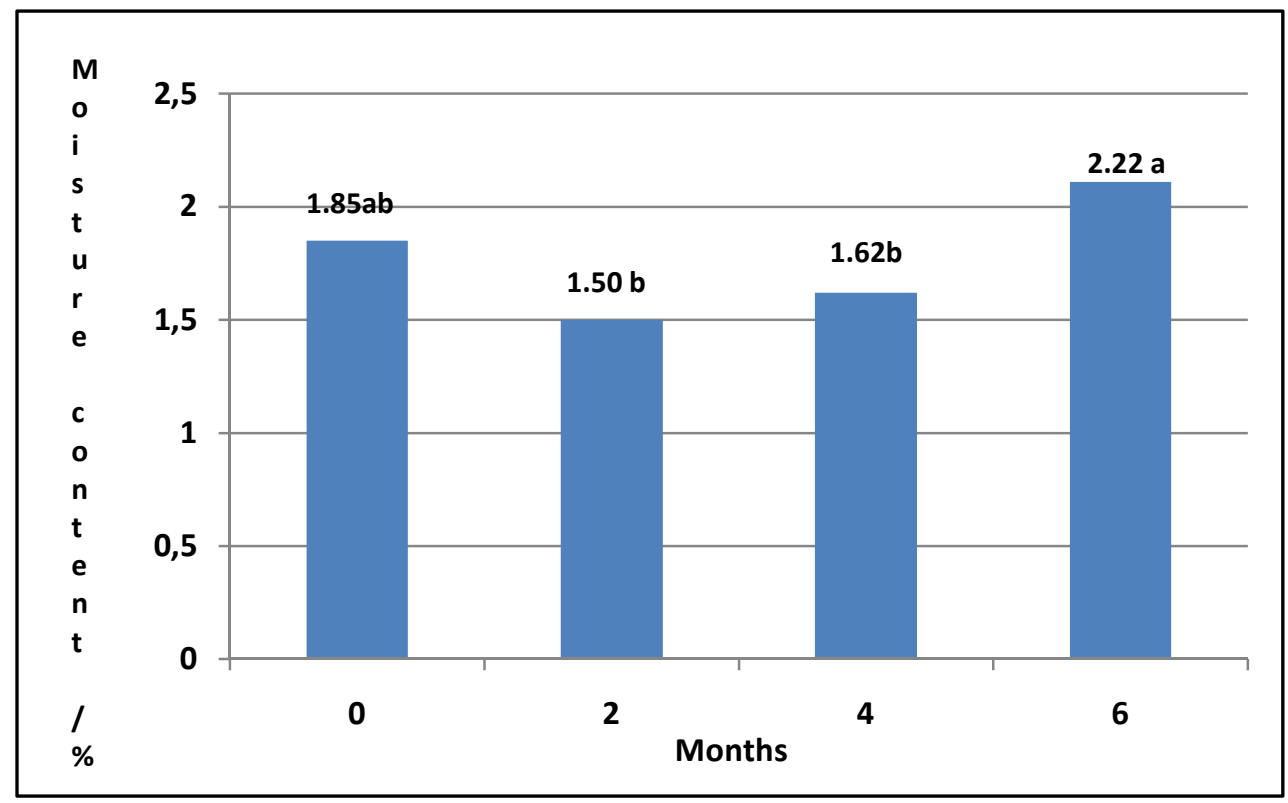

Note: Numbers followed by the different letter at the graph are significantly differenced at $5 \%$ of DMRT

Figure 2. Effect of storage on the moisture content of coconut chips 
Table 4. Effect of storage time on the characteristic of coconut chips

\begin{tabular}{|c|c|c|c|c|}
\hline \multirow{2}{*}{ Storage Times } & \multicolumn{4}{|c|}{ Organoleptic Test } \\
\cline { 2 - 5 } & Color & Flavor & Taste & Crunchy \\
\hline 0 months & $3.41 \mathrm{~b}$ & $3,56 \mathrm{a}$ & $3.91 \mathrm{a}$ & $4.06 \mathrm{a}$ \\
\hline 2 months & $3.65 \mathrm{a}$ & $3.44 \mathrm{a}$ & $3.85 \mathrm{a}$ & $3.73 \mathrm{~b}$ \\
\hline 4 months & $3.73 \mathrm{a}$ & $3.33 \mathrm{a}$ & $3.75 \mathrm{a}$ & $3.58 \mathrm{~b}$ \\
\hline 6 months & $3.80 \mathrm{a}$ & $3.44 \mathrm{a}$ & $3.88 \mathrm{a}$ & $4.09 \mathrm{a}$ \\
\hline
\end{tabular}

Note: Numbers followed by the different letter at the same column are significantly differenced at $5 \%$ of DMRT

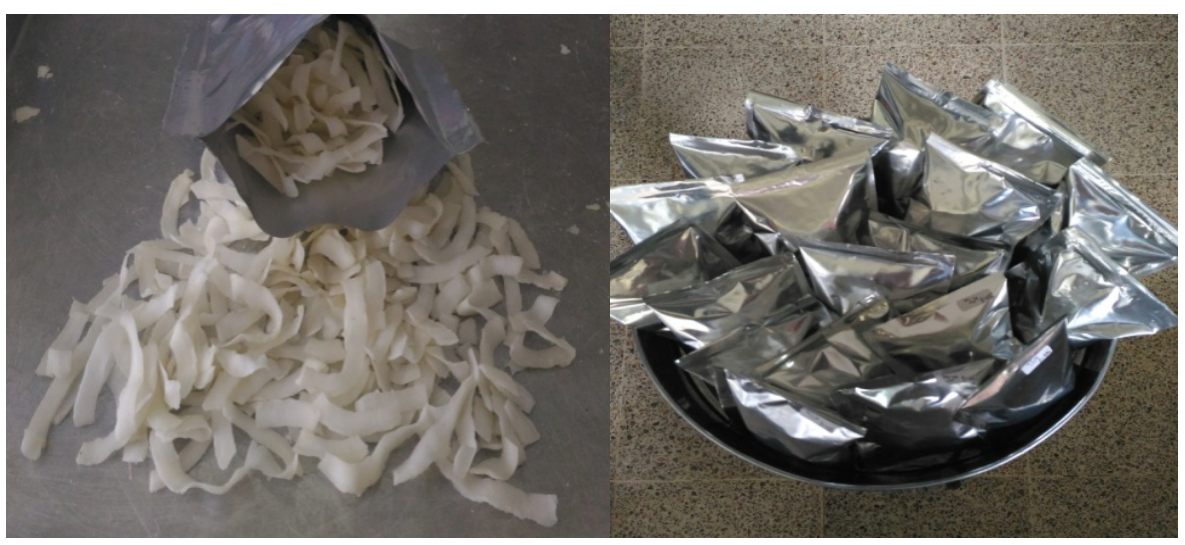

Figure 3. Coconut chips packed with plastic coated aluminum foil

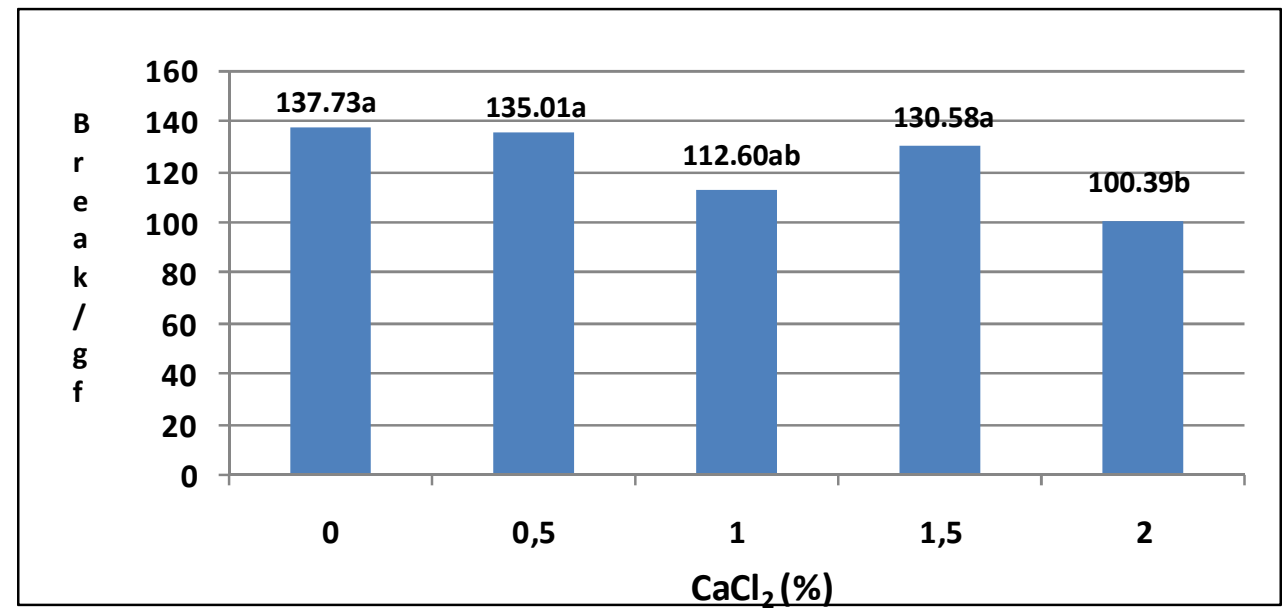

Note: Numbers followed by the different letter at the graph are significantly differenced at $5 \%$ of DMRT

Figure 4. The break values of coconut chips using Texture Analyzer 
Table 5. The color of coconut chips using Chromameter Konica Minolta CR-400

\begin{tabular}{|c|c|c|c|c|}
\hline \multicolumn{2}{|c|}{ Treatment } & \multicolumn{3}{|c|}{ Color Characteristics } \\
\hline $\begin{array}{c}\text { Concentration } \\
\text { of } \mathrm{CaCl}_{2}(\%)\end{array}$ & $\begin{array}{l}\text { Storage } \\
\text { (months) }\end{array}$ & $\mathrm{L}$ & $\mathrm{a}$ & $\mathrm{b}$ \\
\hline 0.0 & & 77.40 & 4.13 & 4.17 \\
\hline 0.5 & & 76.27 & 4.25 & 3.93 \\
\hline 1.0 & 0 months & 74.45 & 3.75 & 5.15 \\
\hline 1.5 & & 75.85 & 3.99 & 4.00 \\
\hline 2.0 & & 77.06 & 3.98 & 3.33 \\
\hline 0.0 & & 75.23 & 2.98 & 3.40 \\
\hline 0.5 & & 74.36 & 3.06 & 3.15 \\
\hline 1.0 & 2 months & 73.28 & 2.80 & 5.02 \\
\hline 1.5 & & 73.94 & 2.78 & 3.58 \\
\hline 2.0 & & 73.88 & 2.81 & 3.46 \\
\hline 0.0 & & 74.46 & 4.10 & 4.93 \\
\hline 0.5 & & 74.87 & 2.26 & 2.55 \\
\hline 1.0 & 4 months & 73.76 & 3.91 & 3.85 \\
\hline 1.5 & & 73.97 & 4.02 & 3.49 \\
\hline 2.0 & & 74.09 & 3.75 & 3.19 \\
\hline 0.0 & & 77.65 & 3.19 & 3.21 \\
\hline 0.5 & & 77.33 & 3.36 & 3.25 \\
\hline 1.0 & 6 months & 77.35 & 2.97 & 3.97 \\
\hline 1.5 & & 76.76 & 3.09 & 2.88 \\
\hline 2.0 & & 76.39 & 3.14 & 2.78 \\
\hline
\end{tabular}

The results of coconut chips color measurement with immersion in $(0-2 \%) \mathrm{CaCl}_{2}$ solution:

1. $\quad$ storage time for 0 months, $\mathrm{L}$ values 74.45 77.40 ; a (Red and green color between 3.75-4.25); and b (yellow and blue color between 3.33-5.15).

2. $\quad$ storage time for 2 months, $\mathrm{L}$ values 73.28 75.23; a (Red and green color between
2.78-3.06); and $\mathrm{b}$ (yellow and blue color between 3.15-5.02).

3. $\quad$ storage time for 4 months, $L$ values 73.7674.87; a (Red and green color between 22.26-4.10); and b (yellow and blue color between 2.55-4.93).

4. $\quad$ storage time for 6 months, L values 76.3977.65; a (Red and green color between 2.97-3.36); and b (yellow and blue color between 2.88-3.25). 
Based on an organoleptic test (Table 3), the color of coconut chips is 3.57-3.69 (normal to near like) not influenced by $\mathrm{CaCl}_{2}$ concentration but influenced by the length of storage with range values 3.41-3.80 (normal to near like). The results of measurement coconut chips color at immersion in $(0-2 \%) \mathrm{CaCl}_{2}$ concentration using Chromameter Konica Minolta CR-400 Showed that the product is still predominantly bright white (Figure 3 ) with a value up to 6 months between 76.39-33.65. While, a value between 2.97-3.36 and b 2.78-3.97. The $a$ and $b$ values still lower compared than range value for a (red and green color $0-60$ ) and $b$ values (yellow and blue color 0-60). This might because by temperature drying below $100^{\circ} \mathrm{C}$, so the caramelization process is avoided. Ginting (2014) reported that the color of cassava chips without immersion in acetic acid solutions have an $L$ value 62.06, a 1.61, and b 27.12. This is due to processing with the deep fat fryer system at $170^{\circ} \mathrm{C}$ for 1.45 minutes, so that the caramelization process occurs.

\section{Conclusion}

The coconut chips obtained by processing coconut meat from 9 month old DMT coconut variety contain $2.36-2.49 \%$ moisture, $2.36-2.55 \%$ ash, $3.87-5.35 \%$ protein, $37.31-45.35 \%$ fat, 50.15 $53.23 \%$ carbohydrate, and $4.93-5.48 \%$ crude fiber. Immersion in $\mathrm{CaCl}_{2}$ solution and storage time increased the water content of coconut chips, but still far from the maximum limit on commercial chips. Based on the organoleptic test, immersion in $0-2 \% \mathrm{CaCl}_{2}$ solution does not have any effect on color, flavor, taste, and crispness of coconut chips. Likewise, the storage time did not affect the flavor and taste of coconut chips, but color and crispness changed during storage.

The crispness of coconut chips using Texture Analyzer influenced by immersion in $\mathrm{CaCl}_{2}$ solution. The higher concentration of $\mathrm{CaCl}_{2}$ solution used in immersion, the break value decreases. This proves that only a smaller pressure is needed in gram force for a break or destroy the coconut chips, which can be interpreted that coconut chips have a good crispness. The measurement of color using a Chromameter Konica Minolta CR-400 showed that the product is still predominantly bright white because of white value up to 6 months between 76.39-33.65.

\section{References}

AOAC. 1995. Official Methods of Analysis of The Association Analytical Chemistry, Inc., Washington D.C.

AOAC. 1997. Official Methods of Analysis. 15 ${ }^{\text {th }}$ ed. Arlington. Virginia

Anonim, 2002. Omega 9. Leaflet. Mead Johnson.

Anonim, 2005. Label Produk Roasted Sweet Coconut, Bangkok-Thailand.

Anonim. 2019. Coconut Chips. Coconut Development Board, Kochi. http://coconutboard.nic.in/docs/coconutchi ps.pdf. [Download, 8 Maret 2019].

Balitpalma, 2018. Leaflet. Kelapa Dalam Unggul. Balai Penelitian Tanaman Palma (Balit Palma). J1. Raya Mapanget, PO. Box 1004, Manado 95001. http://balitka.litbang.pertanian.go.id.

Butler, C. 2019. Does Coconut Flour Have Starch? Does Coconut Flour Have Starch? https://www.ehow.com/info_12331468_co conut-flour-starch.html [Download, 29 April 2019].

FAO and WHO. 1991. Guidelines on Formulated Supplementary Foods for Older Infants and Children. CAC/GL. 081991.

Http://hftag.gain-health.org [Diunduh Tgl 30 Januari 2014]. 10p.

Ginting, F.S. 2014. Pengaruh perendaman umbi singkong dalam larutan asam asetat terhadap karakteristik mutu keripik singkong. Skripsi pada Fakultas Teknologi Pertanian, IPB. 61 Halaman.

Masa, D.B dan E.P. Montecillo, 2002. Production and marketing of coconut chips and crips. A Phillipine Experince. Cocoinfo International 9(2):5-7.

Kemp, R., Keegan, E. Suzanne. 2000. Calcium Chloride. Ullmann's Encyclopedia of Industrial Chemistry, Weinheim: WileyVCH， doi:10.1002/14356007.a04 547. 
[Download, 3 Mei 2019).

Nainggolan, K. 2004. Strategi dan kebijakan pangan tradisional dalam rangka ketahanan pangan. Disampaikan pada Seminar Nasional Peningkatan Daya Saing Pangan Tradisional, Bogor 6 Agustus. 20 Hal.

Nisak,W. 2007. Pengaruh lama simpan buah dan lama perendaman dalam larutan kalsium khlorida $\left(\mathrm{CaCl}_{2}\right)$ terhadap kualitas keripik pepaya (Carica papaya 1.). http://eprints.umm.ac.id/9798/1/.

[Download, 6 Oktober 2016).

PCA Administrative Order No. 003, Series of 1981. Republic of the Philippines. Philippine Coconut Authority. Rules and Regulations Governing the Export and Export Pricing, Marketing, Traiding and Distribution of Copra, Coconut Oul and Other Coconut Products. Spsissuances.da.gov.ph [Download, 7 Oktober 2019].

Peleg, M. and E.B. Bagley. 1983. Physical Properties of Food. Connecticut: AVi Publishing Company, Inc.

Rindengan, B., A. Lay., H. Novarianto dan Z. Mahmud. 1996. Pengaruh jenis dan umur buah terhadap sifat fisikokimia daging buah kelapa hibrida dan pemanfaatannya. Jurnal Penelitian Tanaman Industri 1(6):263-277.

Rindengan, B. 2002. Kandungan asam lemak omega 9 dan omega 6 pada beberapa jenis kelapa. Buletin Palma 28: 1-6.

Rindengan, B., M. Terok dan G. Elvianus. 2004. Pengolahan Makanan Ringan dari Daging Buah Kelapa. Monograf Pascapanen Kelapa. Balai Penelitian Tanaman Kelapa dan Palma Lain (Balitka). Hal 42-88.
Rindengan, B. 2018. Kelapa sebagai sumber gizi alternatif. Warta Puslitbangbun 24(3): 2732.

Ramsey. 2002. http://www.konicaminolta.com/ instruments/download/catalog/color/pdf/ cr400 catalog eng.pdf. [Download, 21 Februari 2014].

Soewarno, S.T. 1985. Penilaian organoleptik untuk industri pangan dan hasil pertanian. Brata Aksara. Jakarta. 121 halaman.

Sanchez, P., A.S. Herman, B. Enie dan P.K. Thampan. 1996. Coconut Processing Technology Information Document. Coconut Food Process. APCC.

Sari, C.I., 2010. Pembuatan Keripik Pepaya (Carica papaya L.) Dengan Vacuum Frying (Kajian Oleh Varietas Pepaya Dan Pengaruh Perendaman Dalam Berbagai Konsentrasi Kalsium Klorida $\left(\mathrm{CaCl}_{2}\right)$ Terhadap Sifat Fisika-Kimia Dan Organoleptik. Department of Agroindustry. http://skripsi.umm.ac.id/ files/disk1/98/jiptummpp-gdl-s1-2005cendrainde-4871-Pendahul-n.pdf. [Download, 5 Oktober 2016).

Tenda, E.T., H.G. Lengkey dan J. Kumaunang. 1997. Produksi dan kualitas buah tiga kultivar kelapa genjah dan tiga kultivar kelapa dalam. Jurnal Penelitian Tanaman Industri. 3(2): 64-71.

Tuwitii. 2010. Kalsium Klorida. http://blogkimia.wordpress.com/kalsium klorida [Download, 17 Maret 2011].

Winarno, F.G. 1986. Kimia Pangan dan Gizi. PT Gramedia, Jakarta. 